総合論文

\title{
イオン交換反応の微視的な視点からの解明の試み 一層状構造チタン酸塩の場合一
}

\author{
佐々木 高義 \\ 科学技術庁 無機材質研究所 \\ ₹ 305 茨城県つくば市並木 $1-1$
}

(1993年2月 10 日受理)

\section{要 旨}

層状構造を有する無機イオン交換体である2種類のチタン酸化物（四チタン酸塩とウロコ鉄 鉱類似千夕ン酸塩) のイオン交換性を, 化学量論的な側面からだけではなく, 原子・分子レベ ルに立った微視的な視点も加味して解明した。粉末 X線回折データ, 赤外吸収スペクトル等か らの情報を総合してホスト物質の構造を, 交換席の位置, 種類まで含めて明かにした。さら に, イオン交換過程での格子定数, 結晶対称性の解析およびリートベルト結晶構造精密化等を 行なうことにより，陽イオンが層間に侵入するとどのような配列をとり，それに対応してホス ト骨格がどのように変化するかについて調べ，イオン交換機構との関連を考察した。その結果 これら2種類の層状チタン酸化物のイオン交換反応には結晶構造の特徵が色濃く反映されてお り，微視的な観点からよく説明できることが明かになった。

\section{1 緒言}

チタンとアルカリ金属の複合酸化物には図 1 に 示したような多様な層状物質 ${ }^{1}$ が知られている。 これらの化合物の層間に存在するアルカリ金属イ オンは交換性に富み, 特に水素型に変換したもの は層状構造を有する特異な含水酸化チタンとして イオン交換体 ${ }^{2-8)}$, インターカレーション材 ${ }^{9-111}$ の観点から盛んに研究されている。また層間にピ
ラーを導入することも可能で触媒・分子小る (12,13)等としても注目を集めている。

この層状チタン酸塩の他にも結晶質の無機イオ ン交換体は数多く知られているが，それらのイオ ン交換性についての基礎研究は主として化学量論 的 (交換等温線, 滴定曲線等) および熱力学的 (キーランドプロット等) アプローチによることが 多い。この種の取り扱いにより交換体の酸・塩基

ささきたかよし 科学技術庁 無機材質研究所 主任研究官（理学博士）

経歴: 昭和 53 年東京大学理学部化学科卒業, 昭和 55 年東京大学大学院理学系研究科修士課 程修了, 同年無機材質研究所入所, 現在にいたる。昭和 61 年 62 年 カリフォルニ ア大学バークレー校博士研究員。

専門: 無機固体化学

趣味 : 囲碁

連絡先 : $=305$ 茨城県つくば市並木 $1-1$ (勤務先) 

A $\mathrm{K}_{2} \mathrm{Ti}_{2} \mathrm{O}_{5}$
B $\mathrm{Na}_{2} \mathrm{Ti}_{3} \mathrm{O}_{7}$
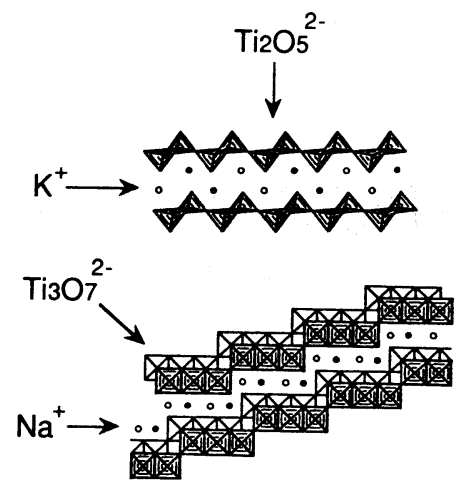
C $\mathrm{K}_{2} \mathrm{Ti}_{4} \mathrm{O} 9$

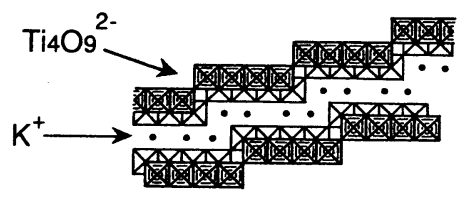
D Cs2Ti5O11

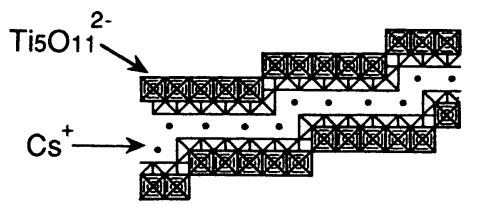
E $\quad$ Ss $x$ Ti2- $x / 4 \square \times 14 \mathrm{O}_{4}$

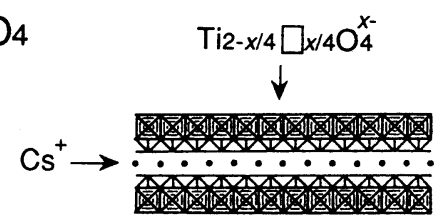
図1層状構造チタン酸塩の組成と結晶構造
$A:$ 二チタン酸塩 ${ }^{(8)} ， B$ : 三チタン酸塩 ${ }^{(b)} ， C$ : 四チタン酸塩 ${ }^{(c, d)}$, $D$ : 五チタン酸塩 ${ }^{(e)} ， E ：$ ウロコ鉄鉱類(似チタン酸塩 ${ }^{(e, f)}$. A ではTiは 五配位 (三角両錐体)，B～Eでは六配位（八面体）を基本としており， これらが頂点および稜を共有して連鎖しホスト層（巨大陰イオン）を形 成する。アルカリ金属イオンはその間に入り電荷を補償する。

性, 選択性に関する情報が得られマクロな面から イオン交換機構についての議論が可能である。こ れに対して原子・分子レベルに立ってイオンがど ういったサイトに侵入し，どのような配位を受け て収まるかといったことを解明することができれ ば学術, 応用の両面にわたって大きな波及効果が 期待される ${ }^{14)}$ にもかかわず, その種の微視的側 面からの取り組みは非常に少ないと言わざるをえ ない。例えば層状構造を有する無機イオン交換体
の代表であるリン酸ジルコニウムとその関連物質 においても, イオン交換により誘起される結晶構 造の変化に関する情報としては層間距離のみを記

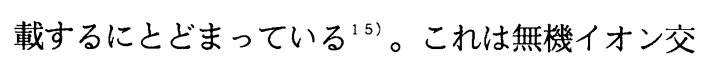
換体の研究対象が粉末あるいはせいぜい $100 \mu \mathrm{m}$ 以下の微結晶に限られていることを勘案すれば仕 万のないことと言えよう。精密な微視的情報を手 に入れるには一般には数百ミクロンの大きさの質 のよい単結晶を使ってX線回折法等により結晶学 
的な解析を行なうのが王道であるが，イオン交換 の立場から見ればそういう結晶は kineticsの問題 もあり不都合な面が多いし，仮にむらのないイオ ン交換が起きたとしてもイオンの出入りによって 結晶の質の低下をきたし満足な解析ができなくな る可能性が高い。以上のような理由でイオン交換 反応をミクロスコーピックな視点から追跡しよう とする場合, 粉末回折データに頼らざるを得ない のが実状である。

冒頭で述べた層状チタン酸塩イオン交換体も瀻 維状もしくは板状の微結晶であるが，単結晶には 程遠く回折データは粉末法によってしか得られな い。しかし単結晶データに比べて質の低い情報し か与えない粉末データであっても, 最近のリート ベルト法の普及 ${ }^{16)}$ とあいまって丹念な解析を行え ばそのイオン交換現象に関してかなりの議論を展 開できる場合がある。ここでは上記の各種層状チ タン酸塩のうち四チタン酸塩 $\mathrm{K}_{2} \mathrm{Ti}_{4} \mathrm{O}_{9}^{1 \mathrm{lc}, \mathrm{d})}$ ，ウロコ 鉄鉱 (Lepidocrocite, $\mathrm{FeO}(\mathrm{OH})$ ) 類似チタン酸塩 $\mathrm{Cs}_{x} \mathrm{Ti}_{2-x / 4} \square_{x / 4} \mathrm{O}_{4}(x \sim 0.7, \square: \text { 空孔 })^{1 \mathrm{le}, \mathrm{f}}$ の場合に ついて化学量論的な取り扱いに加えて微視的な視 点からイオン交換反応の解析を試みた例を紹介す る。

\section{2 交換体の構造 5 ,8}

上記の化合物のうち $\mathrm{K}_{2} \mathrm{Ti}_{4} \mathrm{O}_{9}$ は $\mathrm{K}_{2} \mathrm{O}-\mathrm{TiO}_{2}$ の出発 原料を $\mathrm{K}_{2} \mathrm{MoO}_{4}$ フラックスに $1150^{\circ} \mathrm{C}$ で溶解し, 毎 時 $4{ }^{\circ} \mathrm{C}$ 程度の速度で徐冷することにより長さ $0.5 \mathrm{~mm}$ 太さ $0.01 \mathrm{~mm}$ 程度の繊維状結晶として育成 される ${ }^{17)}$ 。一方 $\mathrm{Cs}_{x} \mathrm{Ti}_{2-x / 4} \square_{x / 4} \mathrm{O}_{4}$ は $\mathrm{Cs}_{2} \mathrm{O}-\mathrm{TiO}_{2}$ を $800^{\circ} \mathrm{C}$ で焼成する（20 時間 $\times 2$ 回）ことによりミ クロンオーダーの板状多結晶体として得られ $ろ^{11,8)}$ 。なおこの場合 $x$ は $0.67 〜 0.73$ の間の值を とり非化学量論性を示す ${ }^{8)}$ 。

こ机らのチタン酸塩を塩酸で処理すると層間に 存在する陽イオンが全て溶出され，それぞれ $\mathrm{H}_{2} \mathrm{Ti}_{4} \mathrm{O}_{9} \cdot 1.2 \mathrm{H}_{2} \mathrm{O}$ (以下 HT として表す), $\mathrm{H}_{x} \mathrm{Ti}_{2-x / 4}$ $\square_{x / 4} \mathrm{O}_{4} \cdot \mathrm{H}_{2} \mathrm{O}$ （以下 HL）が生成したと考えられ
る。これらは一種の固体酸であり無機イオン交換 体として働くが5,6,8)，そのイオン交換性を原子・ 分子レベルで考察するためにはまずその結晶構造 を知らなければならない。以下に粉末 X線回折 データと赤外吸収スペクトル，化学組成に関する 情報を総合することによって交換サイトまで含め て構造を考察した過程を概説する。

$\mathrm{K}_{2} \mathrm{Ti}_{4} \mathrm{O}_{9}$ を酸処理して層間の Kイオンを全て溶 出するとその粉末 X 線回折図形はかなり変化する が (図 2),この構造に特徵的な回折線 (200，020 等）を指定することにより母相と同じ対称性（C 底心単斜格子) で指数付けできた。精密化された 格子定数（表 1 ）のうち $b$ 軸長 $\left(\mathrm{TiO}_{6}\right.$ 八面体の体 対角線長に匹敵）と $c$ 軸長（八面体 4 個が稜共有で 連鎖した構造ブロックの対角線長）にほとんど変 化が見られないことより $\mathrm{Ti}_{4} \mathrm{O}_{9}{ }^{2-}$ のホスト骨格は水 素型に変換された後でも保持されていることが確 認できる（図3）。これに対して $a$ 軸および $\beta$ 角に はかなりの変化が観測され層間距離が $8.75 \rightarrow 9.1 \AA$ に拡がるとともに隣接したホスト層の $c$ 軸に沿っ た相対的な配置も変化することを示している。

次に HTの化学組成が近似的に $\left(\mathrm{H}^{+} \mathrm{H}_{3} \mathrm{O}^{+}\right) \mathrm{Ti}_{4} \mathrm{O}_{9}$ と 表現できることから層間に裸のプロトンとヒドロ ニウムイオンを $1: 1$ に含んでいることが示唆され る。ポーリングがイオン結晶の安定性に関して提 案した静電原子価則 ${ }^{18)}$ に基づけば, 裸のプロトン は最も静電気的に中和されていないホスト骨格表 面の酸素（図3中の矢印）に結合してヒドロキシ ル基を形成すると考えられる。実際この物質の単 位胞の構成成分は $4 \times\left(\mathrm{H}^{+} \mathrm{H}_{3} \mathrm{O}^{+}\right) \mathrm{Ti}_{4} \mathrm{O}_{9}$ であり裸のプ ロトンの個数と矢印で示した酸素が単位胞あたり 4個存在することとが一致し，構造の上からもつじ つまがあう。残りのヒドロニウムイオンは図中に 示したような位置に存在しホスト層の間でつっか い棒的な㗢きをしていると考えられる。

HLの場合も格子定数（表 1）の变化に基づいて 層間距離 $9.4 \AA$ の体心斜方の構造（図4）を有して いることが明かになった ${ }^{8,19)}$ 。酸素 8 個によって 


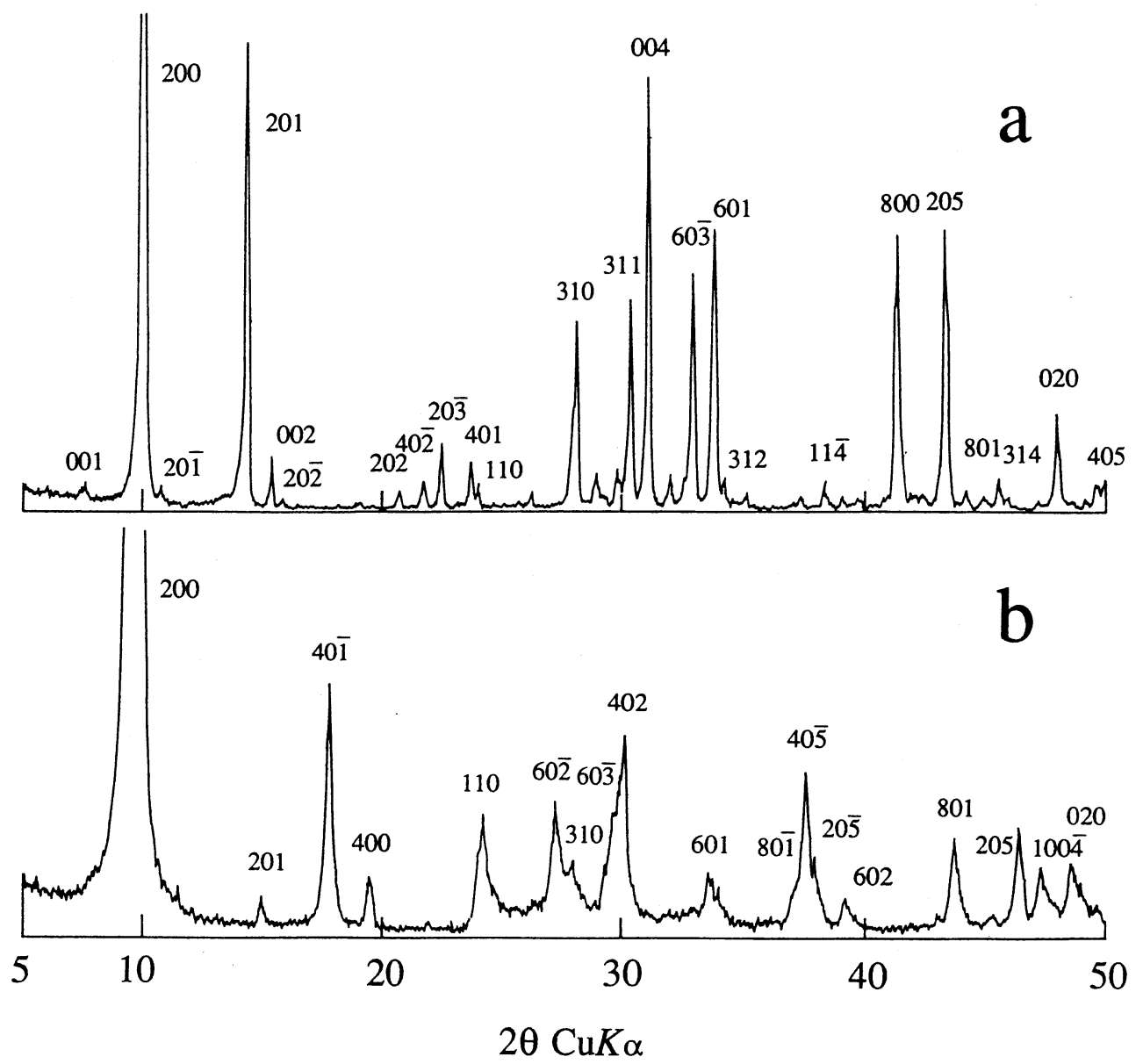

図2四チタン酸カリウムの酸処理に伴う粉末 X線回折パターンの変化

(a) $\mathrm{K}_{2} \mathrm{Ti}_{4} \mathrm{O}_{9}$, (b) $\mathrm{H}_{2} \mathrm{Ti}_{4} \mathrm{O}_{9} \cdot 1.2 \mathrm{H}_{2} \mathrm{O}$

表 1 水素型への変換に伴う格子定数の変化

\begin{tabular}{|lcccc|}
\hline & $a(\AA)$ & $b(\AA)$ & $c(\AA)$ & $\beta\left(^{\circ}\right)$ \\
\hline $\mathrm{K}_{2} \mathrm{Ti}_{4} \mathrm{O}_{9}{ }^{\mathrm{ld})}$ & $18.25(1)$ & $3.792(1)$ & $12.01(1)$ & $106.4(1)$ \\
$\mathrm{H}_{2} \mathrm{Ti}_{4} \mathrm{O}_{9} \cdot 1.2 \mathrm{H}_{2} \mathrm{O}^{5)}$ & $19.968(4)$ & $3.746(1)$ & $12.025(2)$ & $114.01(1)$ \\
\hline $\mathrm{Cs}_{x} \mathrm{Ti}_{2-x / 4} \square_{x / 4} \mathrm{O}_{4}(x=0.7)^{8)}$ & $3.837(1)$ & $17.198(3)$ & $2.960(1)$ & - \\
$\mathrm{H}_{x} \mathrm{Ti}_{2-x / 4} \square_{x / 4} \mathrm{O}_{4} \cdot \mathrm{H}_{2} \mathrm{O}(x=0.7)^{8)}$ & $3.783(2)$ & $18.735(8)$ & $2.978(2)$ & - \\
\hline
\end{tabular}

囲まれる層間の cubic席をすべて水分子が占有し， その約 70\%がヒドロニウムイオンになっている。 これはホスト層表面の酸素の電気的中和度が比較 的高くヒドロキシル化しないためである。
以上のような 2 種類の交換性水素イオンの存在 は $\mathrm{IR}^{5,8)} ， \mathrm{NMR}^{4 \mathrm{~b})}$ によって確認された。HTのIR スペクトル（図 5 ）には $3400 \mathrm{~cm}^{-1}, 1630 \mathrm{~cm}^{-1}$, $970 \mathrm{~cm}^{-1}$ を中心とした3本の特徵的なバンドが観測 


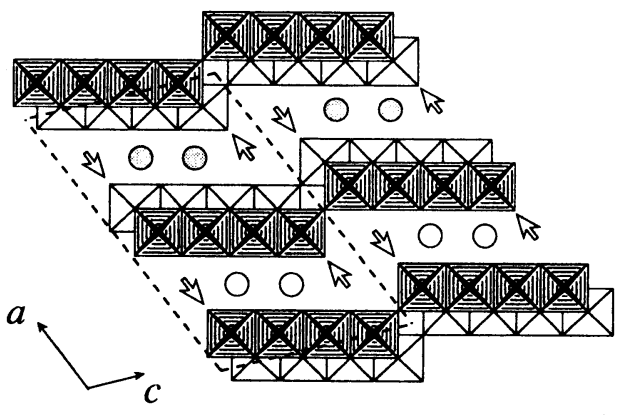

図 $3 \mathrm{HT}\left(\mathrm{H}_{2} \mathrm{Ti}_{4} \mathrm{O}_{9} \cdot 1.2 \mathrm{H}_{2} \mathrm{O}\right)$ の結晶構造

$\Rightarrow$ : ${ }^{-} \mathrm{OH}$ 基, $\mathrm{O}: \mathrm{H}_{3} \mathrm{O}^{+}$at $y=0, \bigcirc: \mathrm{H}_{3} \mathrm{O}^{+}$at $y=1 / 2$

破線で囲んだ範囲が単位格子に相当する。

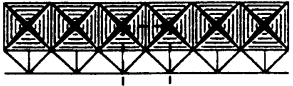

) 0 0:0:0 0 (

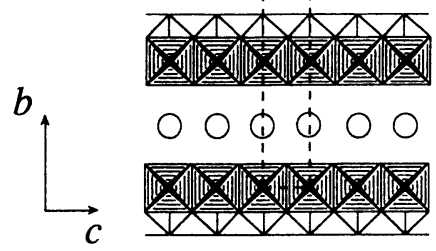

図4 $\mathrm{HL}\left(\mathrm{H}_{\mathrm{x}} \mathrm{Ti}_{2-x / 4} \square_{x / 4} \mathrm{O}_{4} \cdot \mathrm{H}_{2} \mathrm{O}\right)$ の結晶構造

$\mathrm{O}: \mathrm{H}_{2} \mathrm{O}, \mathrm{H}_{3} \mathrm{O}^{+}$at $y=0$,

O : $\mathrm{H}_{2} \mathrm{O}, \mathrm{H}_{3} \mathrm{O}^{+}$at $\mathrm{y}=1 / 2$

破線で囲んだ範囲が単位格子に相当する。

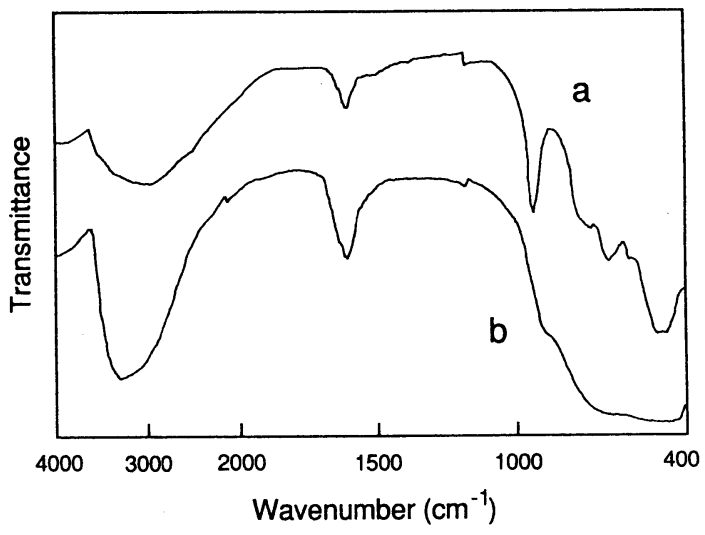

図 5 赤外吸収スペクトル
(a) $\mathrm{HT}\left(\mathrm{H}_{2} \mathrm{Ti}_{4} \mathrm{O}_{9} \cdot 1.2 \mathrm{H}_{2} \mathrm{O}\right)$
(b) $\mathrm{HL}\left(\mathrm{H}_{\mathrm{x}} \mathrm{Ti}_{2-x_{1}} \square_{\mathrm{N}_{4}} \mathrm{O}_{4} \cdot \mathrm{H}_{2} \mathrm{O}\right)$

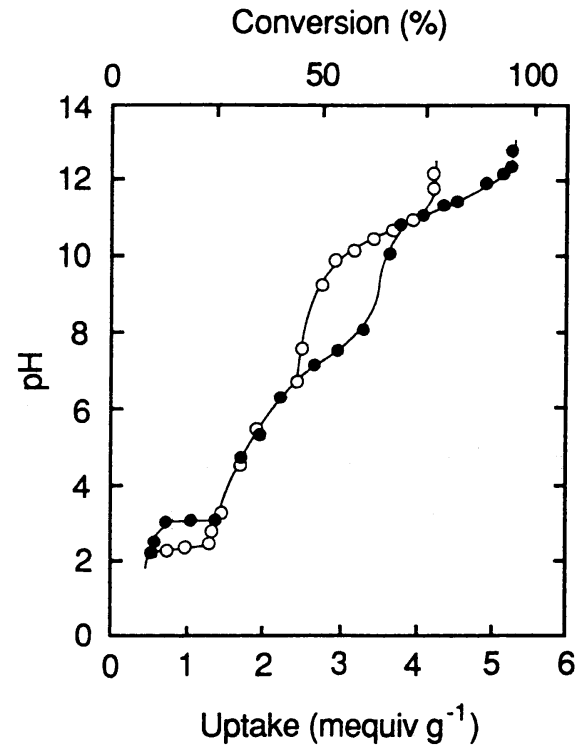

(a)

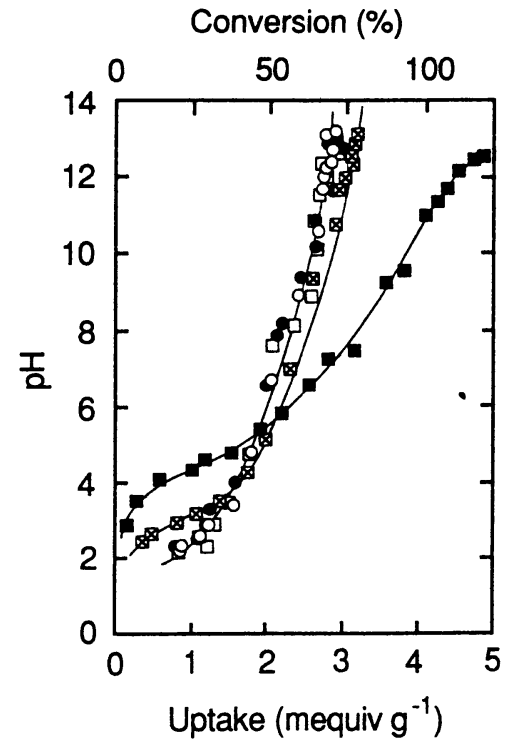

(b)

図6 $\mathrm{pH}$ 滴定曲線
(a) $\mathrm{HT}\left(\mathrm{H}_{2} \mathrm{Ti}_{4} \mathrm{O}_{9} \cdot 1.2 \mathrm{H}_{2} \mathrm{O}\right), \mathrm{Rb}, \mathrm{O}: \mathrm{K}$
(b) $\mathrm{HL}\left(\mathrm{H}_{\mathrm{x}} \mathrm{Ti}_{2-x / 4} \square_{x / 4} \mathrm{O}_{4} \cdot \mathrm{H}_{2} \mathrm{O}\right), \square: \mathrm{Cs}, \mathrm{O}: \mathrm{Rb}$, $\mathrm{O}: \mathrm{K}, \mathrm{X}: \mathrm{Na}$,

夜相 : $M C l-M O H$ 混合溶液, $20 \mathrm{~cm}^{3}(M:$ アルカリ 金属)，イオン強度: 0.1

固相 : $0.2 \mathrm{~g}$, 温度 : $25 \pm 0.5^{\circ} \mathrm{C}$, 接触時間 : 7 日間 
されるのに対して HLには前 2者のシグナルしか現 われない。3本の吸収はそれぞれ水分子または $-\mathrm{O} \mathrm{H}$ 基の伸縮振動，水分子の変角振動， $-\mathrm{OH}$ 基の

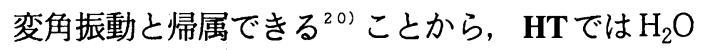
（または $\mathrm{H}_{3} \mathrm{O}^{+}$） と一 $\mathrm{OH}$ 基の両方， HLでは $\mathrm{H}_{2} \mathrm{O}\left(\mathrm{H}_{3}\right.$ $\left.\mathrm{O}^{+}\right)$のみの存在を支持している。

\section{3 化学量論的アプローチによるイオン交 換過程の解明}

図 6に HT, HLのチタン酸をアルカリ金属イオ ンにより滴定した結果を示す ${ }^{5,60,8)}$ 。HTでは理論 交換容量（5.57ミリ当量/g）の1/4ずつの交換量 の点で変曲点が現われ四塩基性を示す。一方 HL では見かけ上一塩基性の固体酸（理論容量 4.12 ミ リ当量 $/ \mathrm{g}$ ）として振る舞う。

次に交換過程での層間距離の変化を粉末 X線回 折法で追跡したところ HT の場合はリン酸ジルコ ニウム ${ }^{15)}$ 等で見られるように不連続的な相変化が 起こることが明かになった。すなわち理論容量の $n / 4(n=1,2,3,4)$ の近傍で単一相が生成し, 中間領域ではその端成分となる層間距離の異なる 2相が混合した。このような検討によりKイオン交 換反応過程は次のようにまとめることができ $る^{5)}$ 。

$\begin{array}{cc}\mathrm{H}_{2} \mathrm{Ti}_{4} \mathrm{O}_{9} \cdot 1.2 \mathrm{H}_{2} \mathrm{O} & {[9.1 \AA]} \\ \text { 第1 ステップ } & \\ \mathrm{K}_{0.5} \mathrm{H}_{1.5} \mathrm{Ti}_{4} \mathrm{O}_{9} \cdot 0.6 \mathrm{H}_{2} \mathrm{O} & {[8.6 \AA]} \\ \text { 第2 ステップ } & {[9.0 \AA]} \\ \mathrm{KHTi}_{4} \mathrm{O}_{9} \bullet 0.5 \mathrm{H}_{2} \mathrm{O} & \\ \text { 第3 ステップ } & {[9.8 \AA]} \\ \mathrm{K}_{1.5} \mathrm{H}_{0.5} \mathrm{Ti}_{4} \mathrm{O}_{9} \cdot 1.2 \mathrm{H}_{2} \mathrm{O} & \\ \text { 第 } 4 \text { ステップ } & \\ \mathrm{K}_{2} \mathrm{Ti}_{4} \mathrm{O}_{9} \cdot 2.2 \mathrm{H}_{2} \mathrm{O} & {[10.9 \AA]}\end{array}$

但し角括弧内の数字は層間距離（200面間隔）を 示す。他のアルカリ金属イオンでも若干の差異は 見られるものの基本的に理論容量の $n / 4$ の点を区 切りにした段階的な反応スキームを与える
一方 HLでは様相が異なり理論容量の約 $70 \%$ ま ではいずれの陽イオンも固溶体を作りながら層間 に侵入した ${ }^{19)}$ 。これに伴って層間距離は交換前の $9.4 \AA$ から連続的に減少して交換率 $70 \%$ 付近では 9 Å前後になった。 K, Rb, Csイオンではこの交換 率で反応は停止するが， Na， Liではさらに反応が 進み層間距離が $11 \AA$ 以上に膨潤した相が生成し た。

\section{4 イオン交換過程と結晶構造の対応付 け5, 19)}

3項で記述したイオン交換過程を微視的な観点 から解釈する手始めとして結晶構造の特徵がよ゙の ように反映されているかについて考察した。その 結果以下に記述する通り独立な層間の単位がイオ ン交換挙動に強く反映されていることが示された。

HTではいわゆる「単位層間」は単位胞半分に 相当する。（単位胞には 2 個の層間が含まれるが (図3参照)，これらは $b$ 軸に沿ったレベルが異なる だけで化学的には等価である。）この「単位層間」 にはヒドロニウムイオン 2 個とヒドロキシル基の プロトン2個の計 4 個の交換サイトが存在する。こ れを 1 個ずつ順番に陽イオンが置換していくと考 えれば(1)の反応スキームをよく説明できる。さら に反応過程での化学組成の変化に注意すると第 1 ステップでは層間に侵入した陽イオンとほぼ等し い量の水が吐き出されているのに対して第2 ステ ップでは含水量はほとんど変化しない。これは第 1ステップではKイオンはヒドロニウムイオンを置 き換え，第2ステップでは裸のプロトンと交換し ていることを暗示しており，交換席が置換される 順番に関する情報を与えるとともに HTが 2 種類の 交換性水素イオンを含んでいることをイオン交換 の面からも支持している。

一方 HLの「単位層間」は隣り合ったホスト層 表面の酸素 8個に囲まれた cubic cavityにあたり， 交換席は 1 つしか含まれていない。このため部分 交換相を生成する相変化を起こしにくく一塩基性 


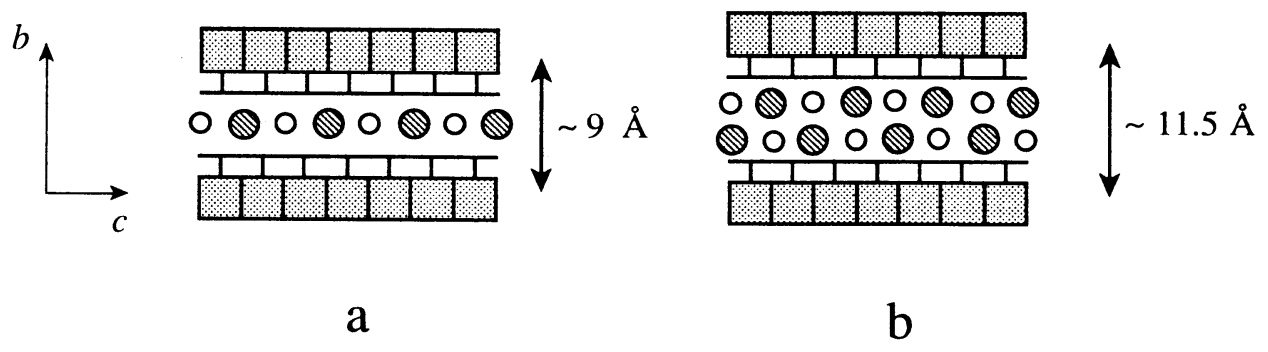

図7ＨLの層間に侵入した陽イオンの配列モデル
(a)一重層（交換率 $70 \%$ 以下),
(b) 二重層
Q $: \mathrm{H}_{2} \mathrm{O}, \mathrm{H}_{3} \mathrm{O}^{+}$

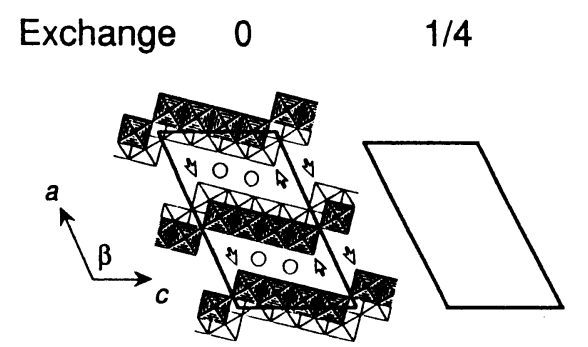

$1 / 2$

$3 / 4$

$1 / 1$

$\begin{array}{lrrrrr}a(\AA) & 19.968(4) & 19.303(3) & 18.708(9) & 22.267(9) & 22.399(5) \\ b(\AA) & 3.746(1) & 3.752(1) & 3.770(2) & 3.782(2) & 3.793(1) \\ c(\AA) & 12.025(2) & 12.078(3) & 12.005(7) & 12.086(7) & 12.036(2) \\ \beta\left({ }^{\circ}\right) & 114.01(1) & 116.76(2) & 104.54(7) & 117.94(5) & 103.72(2) \\ d_{200}(\AA) & 9.1 & 8.6 & 9.0 & 9.8 & 10.9\end{array}$

図8 HTへの Kイオン交換過程における層構造の変化 ${ }^{53} \quad d_{200}$ は層間距離に相 当する。

を示すものと考えられる。最初 cubic cavityには全 て水分子（そのうち 70\%がヒドロニウムイオン） が入っているわけであるが, 陽イオンはヒドロニ ウムイオンを置き換えながら層間に侵入する。こ れは交換がおこるとほぼその量に見合うだけの層 間水が滅少することにより明かである。図 7(a)に 模式的に示したように陽イオンが層間の cubic cavityの半分を占有するまでは水分子が間に入り 陽イオン同士の反発を緩和することが可能であ る。ホスト層の電荷密度から計算すると半分占有 した状態がまさに理論交換容量の $70 \%$ に相当す る。このような配置はかなり安定でありKイオン
等でこの交換率で反応が停止することを説明でき る。これに対してNaイオンのようにさらに交換が 進む場合には，陽イオン同士の近接を避けて図中 (b)のように陽イオンと水分子が 2 列に配列すると 推測される。この2重層配列は層間距離が(a)に比 べてほぼ水分子 1 個の厚みに相当する分だけ膨潤 することからも支持される。

\section{5 層間に侵入した陽イオンの配列状態}

\section{a ）結晶対称性に基づく解析 ${ }^{5}$}

HTのKイオン交換過程に出現した部分交換相 の単位胞の大きさをプロット（ $b$ 軸投影）したの 
表 $2 \mathrm{HT}$ のKイオン完全交換相 $\mathrm{K}_{2} \mathrm{Ti}_{4} \mathrm{O}_{9} \cdot 2.2 \mathrm{H}_{2} \mathrm{O}$ の粉末 X線回折データ ${ }^{5}$

\begin{tabular}{|c|c|c|c|}
\hline$h k l$ & $d_{\text {calod, }}, \AA$ & $d_{\text {obsd }}, \AA$ & intens \\
\hline 200 & 10.88 & 10.85 & vs \\
\hline $20 \overline{1}$ & 9.12 & 9.11 & w \\
\hline 201 & 7.16 & 7.16 & $\mathrm{~s}$ \\
\hline $40 \overline{1}$ & 5.45 & \multirow{2}{*}{5.44} & \multirow{2}{*}{$\mathrm{m}$} \\
\hline 400 & 5.44 & & \\
\hline 401 & 4.54 & 4.54 & $\mathrm{~m}$ \\
\hline $20 \overline{3}$ & 3.981 & 3.983 & w \\
\hline 003 & 3.897 & 3.902 & $\mathrm{vw}$ \\
\hline $60 \overline{1}$ & 3.723 & 3.726 & $w$ \\
\hline 600 & 3.627 & 3.623 & $w$ \\
\hline $210^{*}$ & 3.582 & \multirow{2}{*}{3.582} & \multirow{2}{*}{$\mathrm{m}$} \\
\hline 402 & 3.581 & & \\
\hline 601 & 3.252 & 3.252 & $\mathrm{vw}$ \\
\hline $41 \overline{1}^{*}$ & 3.113 & \multirow{2}{*}{3.113} & \multirow{2}{*}{$\mathrm{m}$} \\
\hline $410^{*}$ & 3.111 & & \\
\hline $60 \overline{3}$ & 3.039 & 3.040 & w \\
\hline 004 & 2.923 & 2.920 & $\mathrm{~s}$ \\
\hline 204 & 2.669 & 2.670 & w \\
\hline $41 \overline{3}^{*}$ & 2.610 & \multirow[t]{2}{*}{2.610} & \multirow{2}{*}{$w$} \\
\hline $412^{*}$ & 2.604 & & \\
\hline $80 \overline{3}$ & 2.530 & \multirow{2}{*}{2.528} & \multirow{2}{*}{$\mathrm{s}$} \\
\hline 801 & 2.521 & & \\
\hline $611^{*}$ & 2.469 & 2.470 & vw \\
\hline $40 \overline{5}$ & 2.361 & 2.361 & $\mathrm{vw}$ \\
\hline 605 & 2.220 & \multirow{2}{*}{2.219} & \multirow{2}{*}{$\mathrm{vw}$} \\
\hline 1002 & 2.219 & & \\
\hline 205 & 2.182 & 2.182 & $\mathrm{~m}$ \\
\hline $100 \overline{3}$ & 2.127 & 2.128 & $\mathrm{~m}$ \\
\hline $20 \overline{6}$ & 2.002 & 2.003 & $\mathrm{vw}$ \\
\hline $100 \overline{4}$ & 1.985 & \multirow{2}{*}{1.985} & \multirow[t]{2}{*}{$w$} \\
\hline 405 & 1.984 & & \\
\hline 020 & 1.896 & 1.896 & $\mathrm{~m}$ \\
\hline $120 \overline{2}$ & 1.861 & \multirow{2}{*}{1.862} & \multirow{2}{*}{$\mathrm{m}$} \\
\hline $120 \overline{1}$ & 1.860 & & \\
\hline
\end{tabular}

*は $C$ 底心格子に禁制であることを示す。

が図 8 である。交換に伴い層間距離が伸縮するだ けでなく，隣接したホスト層が $c$ 軸に沿ってスラ イドする。これは層間に侵入したゲストイオンに よりよい配位を与えるためであろうと考えられ る。

交換により引き起こされるもう一つの重要な変 化として結晶対称性の変化が挙げられる。すなわ ち交換前の段階では $C$ 底心単斜胞であったのが
$1 / 4 ， 1 / 2$, 完全交換相では単純格子に変化する。 この現象はホスト骨格は $C$ 底心格子を保っている のに対して層間に入り込んだ陽イオンと水分子が $C$ 底心の関係から外れた並び方をするためである と説明される。これを逆に利用すれば層間での陽 イオンの配置を定性的に解析することが可能とな る。ここでは HTのKイオン完全交換相について の検討例を示す。 


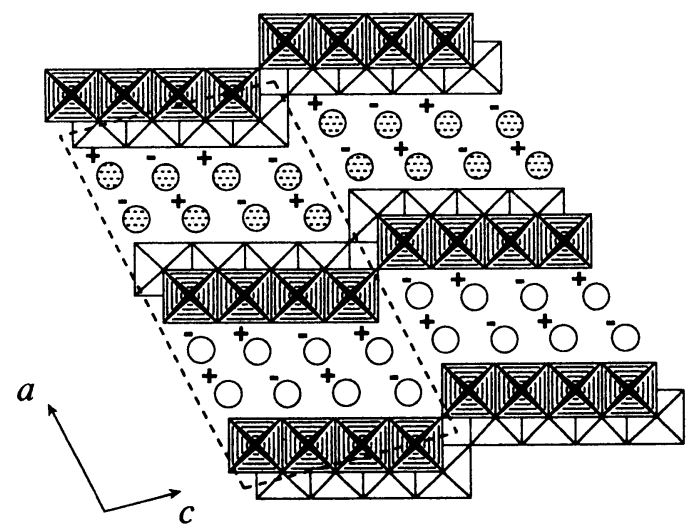

a

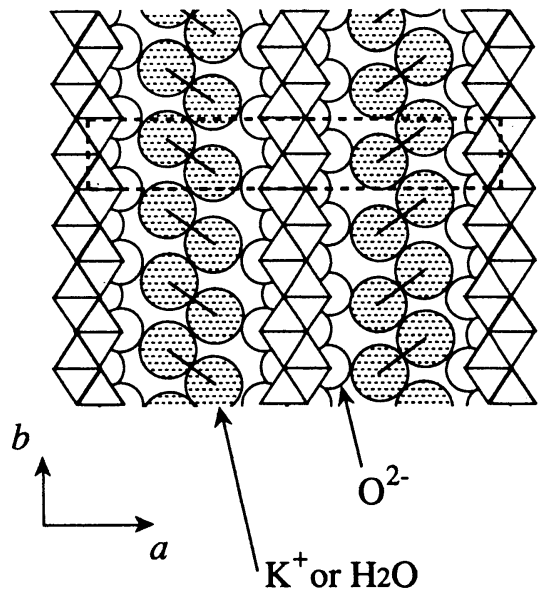

b

図9 $\mathrm{HT}$ の $\mathrm{K}$ 完全交換相 $\mathrm{K}_{2} \mathrm{Ti}_{4} \mathrm{O}_{9} \cdot 2.2 \mathrm{H}_{2} \mathrm{O}$ の構造モデル ${ }^{5)}$

(a) (010) 投影, ${ }^{+} \bigcirc: \mathrm{K}^{+} / \mathrm{H}_{2} \mathrm{O}$ at $y=1 / 2+\delta,-O: \mathrm{K}^{+} / \mathrm{H}_{2} \mathrm{O}$ at $y=1 / 2$ $-\delta,{ }^{+} \mathrm{O}: \mathrm{K}^{+} / \mathrm{H}_{2} \mathrm{O}$ at $y=0+\delta, \quad-\mathrm{O}: \mathrm{K}^{+} / \mathrm{H}_{2} \mathrm{O}$ at $y=0-\delta$,

(b) (001) 投影

この相の X 線データ（表 2）には $C$ 底心格子で は許されない $h+k=$ 奇数の回折線が観測され, 単 純格子に対称性が低下したことが読み取れる。さ らにこれらの反射ではすべて $k=1$ になっており同 じ禁制でも 300，501等の回折線は現われない。 このことは $C$ 底心格子の基本的制約である原子座 標 $(x, y, z)$ と $(x+1 / 2, y+1 / 2, z)$ が等価位 置であるという関係が $y$ 座標に関してのみ破れて いることを意味する。導出の詳細は原報 ${ }^{5)}$ に譲る が, この物質の化学組成, 格子定数等を併せて考 慮することにより図9に示したようにKイオンと 水分子が層間で2列に並びしかも（010）面に対し て傾いているという配置が明かになった。実際に は対称性を満足する傾き方には 3 通りあり，回折 強度を計算して実測値との一致をみることにより 図9のモデルが選ばれた。このような配置を短距

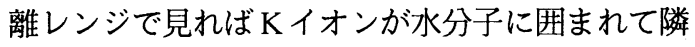
のイオンと遮蔽され, 安定に存在できると考えら れる。このことは四チタン酸カリウム $\mathrm{K}_{2} \mathrm{Ti}_{4} \mathrm{O}_{9}$ が 高い吸湿性を示すこと ${ }^{21)}$ と密接に関連している。
すなわちこの層間では Kイオン同士がむきだしで 接触するため不安定であり空気中の水分を吸収し て図9に示した水和状態をとろうとすると説明さ れる。

\section{b ）リートベルト解析の適用 ${ }^{91}$}

近年リートベルト法と呼ばれる結晶構造精密化 手段が急速に普及してきている ${ }^{16)}$ 。これを用いれ ば原子座標まで求めることができ，より定量的な 議論が可能となる。ここでは 4 項でその層間配置 モデルを議論した HLのKイオン飽和交換相につ いてその構造を解析し, それに基づいてイオン交 換機構との関連について考察した例を示す。

この相は粉末 X 線回折デー夕の指数付けの結果 体心斜方晶であることが確認されたのでホスト層 $\mathrm{Ti}_{1.825} \square_{0.175} \mathrm{O}_{4}^{0.7-}$ をその対称性を満足するように 配置したモデル図から Ti とOの原子座標の初期值 を得た。これを使って解析を進めて Ti と Oの座 標, 温度因子を精密化するとともに, 層間の K イ オン, 水分子の位置はフーリエ合成により求め 
た。フーリエ合成図では図 10(a)中に○印で示した 位置に電子密度の高まりが見られ，この位置にK イオンと水分子が 50\%ずつ混合した仮想的な原子 種を 0.5 個ずつ置いてやれば満足すべきフィッテ イングができることがわかった。この解析結果は Localに見れば層間で図 10(b)のようにKイオンと 水分子が $c$ 軸方向に交互に配列していると考えら れ，図7(a)の配列モデルを支持している。この $\mathrm{K}$ イオンの位置は cubic position（図 10(a) 中の $\times$ で 示した 8 配位位置) から大きくずれており，ホス 卜層表面の酸素 2 個ずつと $c$ 軸に沿って前後に存在 する水分子の酸素 1 個ずつにより 6配位されている

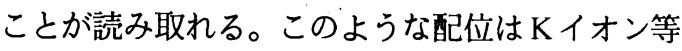
では安定と考えられ，理論交換容量の $70 \%$ を消費 した点で反応が停止することを矛盾なく説明でき る。これに対して $\mathrm{Na}$ のよう小さなサイズの陽イ オンでは比較的安定性に乏しくこの配列を壊して さらにイオンが入り込むと解釈することができ
る。

リートベルト法ではいかに現実に近い初期構造 モデルを組み立てるかが精密化の可否を握ってい るといっても過言ではない。無機イオン交換体で はイオンが出入りしてもホスト骨格には通常大き な変化が起きないものであり, 上記の例のように 残りのゲストイオン，水分子等の配置だけを対称 性もしくはフーリエ合成に基づいて求め比較的容 易にモデルを組み立てることができる。その意味 でリートベルト法を適用しやすい系であると言え よう。

\section{6 結語}

以上層状チタン酸塩について，微視的な視点を 加味してそのイオン交換性を解明，解釈した例を 記述した。結晶学的な解析から抽出される原子・ 分子レベルの情報と従来の化学量論的な取り組み 等から得られるいわばマクロな情報を相補的に用
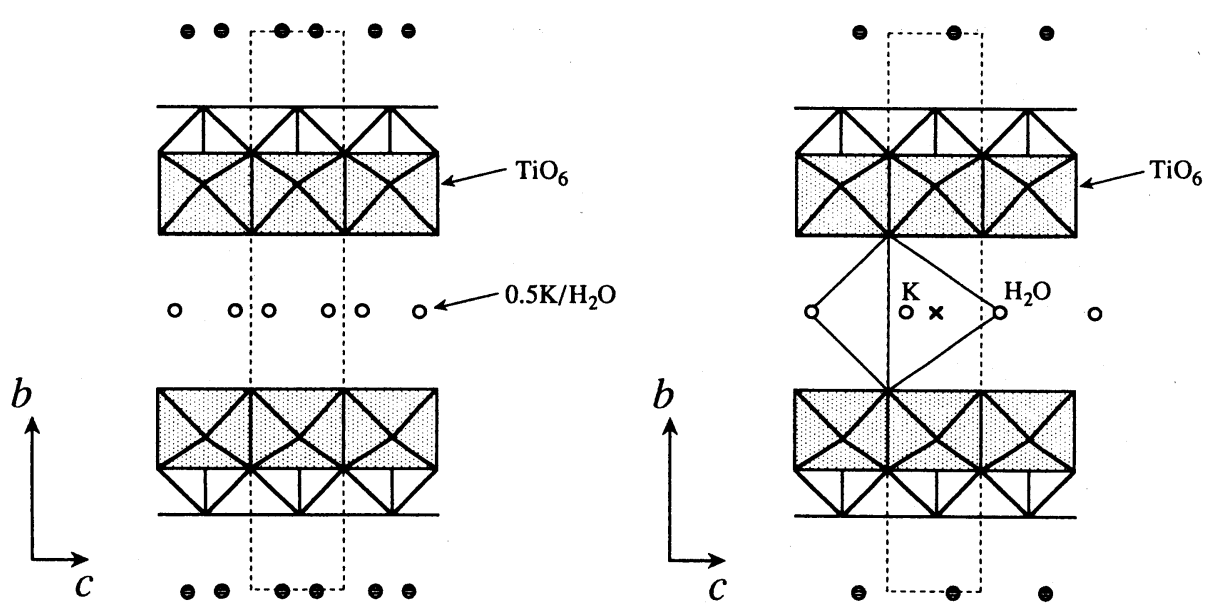

a

b

図10 $\mathrm{HL}$ の $\mathrm{K}$ 飽和交換相 $\mathrm{K}_{0.5} \mathrm{H}_{0.2} \mathrm{Ti}_{1.825} \square 0.175 \mathrm{O}_{4} \cdot 0.6 \mathrm{H}_{2} \mathrm{O}$ の結晶構造

(a) 精密化結果 体心斜方晶 $I \mathrm{mmm}, \quad a=3.7893(3)$

$\AA, b=17.915(3) \AA, c=2.9847(3) \AA$

$R_{w p}=0.097, R_{p}=0.071, R_{l}=0.089, R_{F}=0.053$

(b) 短距離配列 
いることによってイオン交換現象のより深い理解 が可能となる。最近のリートベルト結晶構造精密 化法の進歩もありイオン交換の研究にもより積極 的に微視的な立場からの考察を取り入れた研究が 増えることを念願する。

\section{謝辞}

本研究は無機材質研究所の藤木良規博士, 小松 優博士，渡辺遵博士をはじめ関係各氏の協力をい ただき共同で行なったものである。ここに記して 謝意を表します。

\section{文 献}

1) a) S. Andersson and A. D. Wadsley, Acta Chem. Scand., 15, 663 (1961). b) S. Andersson and A. D. Wadsley, Acta Crystallogr., 14, 1245 (1961). c) A. Verbaere and M. Tournoux, Bull. Soc. Chim. Fr., 4, 1237 (1973). d) M. Dion, Y. Piffard and M. Tournoux, J. Inorg. Nucl. Chem., 40, 917 (1978). e) I. E. Grey, I. C. Madsen, J. A. Watts, L. A. Bursill and J. Kwiatkowska, J. Solid State Chem., 58, 350 (1985). f) I. E. Grey, I. C. Madsen and J. A. Watts, J. Solid State Chem., 66, 7 (1987).

2) T. Sasaki, Y. Komatsu and Y. Fujiki, Solvent Extr. Ion Exch., 1, 775 (1983).

3) a) H. Izawa, S. Kikkawa and M. Koizumi, J. Phys. Chem., 86, 5023 (1982). b) H. Izawa, S. Kikkawa and M. Koizumi, J. Solid State Chem., 60, 264 (1985). c) H. Izawa, S. Kikkawa and M. Koizumi, J. Solid State Chem., 69, 336 (1987).

4) a) R. Marchand, L. Brohan and M. Tournoux, Mater. Res. Bull., 15, 1129 (1980). b) R. Marchand, L. Brohan, R. M'bedi and M. Tournoux, Rev. Chim. Mineral., 21, 476 (1984). c) M. Tournoux, R. Marchand and L. Brohan, Prog. Solid St. Chem., 17, 33 (1986).
5) T. Sasaki, M. Watanabe, Y. Komatsu and Y. Fujiki, Inorg. Chem., 24, 2265 (1985).

6) a) T. Sasaki, M. Watanabe, Y. Komatsu and Y. Fujiki, Bull. Chem. Soc. Jpn., 58, 3500 (1985). b) T. Sasaki, Y. Komatsu and Y. Fujiki, Mater. Res. Bull., 22, 1321 (1987). c) T. Sasaki, Y. Komatsu and Y. Fujiki, Inorg. Chem., 28, 2776 (1989).

7) T. Sasaki, Y. Komatsu and Y. Fujiki, Chem. Mater., 4, 894 (1992).

8) T. Sasaki, Y. Komatsu and Y. Fujiki, J. Chem. Soc., Chem. Commun., 817 (1991)

9) P. Clément and R. Marchand, C. R. Acad. Sci. Paris Ser. II, 296, 1161 (1983).

10) H. Izawa, S. Kikkawa and M. Koizumi, Polyhedron, 2 , 741 (1983).

11) H. Miyata, Y. Sugahara, K. Kuroda and C. Kato, J. Chem. Soc., Faraday Trans. 1, 84, 2677 (1988).

12) S. Cheng and T. C. Wang, Inorg. Chem., 28, 1283 (1989).

13) M. W. Anderson and J. Klinowski, Inorg. Chem., 29, 3260 (1990).

14) 脇博彦 日本イオン交換学会誌, 3, 37 (1992).

15) A. Clearfield, "Inorganic Ion Exchange Materials", p1, A. Clearfield ed. CRC Press, Inc., Boca Raton, Florida (1982).

16）a）泉富士夫 鉱物学雑誌, $\mathbf{1 7}, 37$ (1985). b) 泉富士夫 日本結晶学会誌, 34, 76 (1992).

17）藤木良規, 太田進啓, 案業協会誌， 88, 111 (1980).

18) L. Pauling, "The Nature of the Chemical Bond", p547, Cornell University Press, Ithaca, New York (1960).

19) T. Sasaki, 投稿中

20) Y. I. Ryskin, "The Infrared Spectra of Minerals", p137, V. C. Farmer, Ed., Mineralogical Society; London (1974).

21）藤木良規, 泉富士夫, 大坂俊明, 渡辺遵, 窯業協会 誌, 85, 475 (1977) 


\title{
Microscopic Interpretation of the Ion-Exchange Reactions in the Layered Titanates
}

\author{
Takayoshi SASAKI \\ National Institute for Research in Inorganic Materials \\ 1-1 Namiki, Tsukuba, Ibaraki 305, Japan
}

(Accepted Feburary 10, 1993)

\begin{abstract}
Summary
Ion-exchange properties of two types of the layered titanates (Terta- and Lepidocrocite related titanates) have been examined not only from a stoichiometric aspect but also from a microscopic viewpoint. The X-ray diffraction study in combination with infrared data has revealed the crystal structures of the host materials including the location and kinds of exchangeable protons. Furthermore, the structural changes during the ion-exchange processes have been followed by analyzing cell parameters, symmetry and structure itself (Rietveld refinements), which has given insight on how the host materials accommodate guest cations. It has been demonstrated that the features of ion-exchange reactions are well explained on the basis of the microscopic information.
\end{abstract}

